\title{
Cutting through the fourth wall: the violence of home invasion in Michael Haneke's Funny Games
}

I am convinced we have a degree of delight, and that no small one, in the real misfortunes and pains of others

Burke (1757: 39)

\section{CLOSE-UP}

A slim, dark-haired youth moves into the frame. The camera pans with him as he walks into a kitchen. He opens a fridge and picks out ingredients. We hear the noise of motor racing from an off-screen television. The character is dressed all in white: white sneakers, socks, shorts and a long-sleeved top. There is a sense of disquiet. The white cotton gloves seem out-of-place (Douglas, 1966). Surely the whiteness of the gloves will be spoilt through contact with the food? The character looks off-camera and calls 'can I get anyone anything?' He is answered with the percussive boom of a shotgun. The youth makes his selection and crosses the kitchen to assemble his sandwich. Whilst he butters the bread, we hear the drone of the cars from the television. The noise of hyper-ventilating joins it. We hear a struggle. Cheese goes into the sandwich. A scream. The sandwich is cut on the horizontal.

\section{LEAN-OUT: Introduction}

The above is a description of a key sequence that comes approximately an hour into Michael Haneke's 1997 film Funny Games, as well as the almost shot-forshot remake Funny Games U.S. (2007). I highlight it here as it demonstrates the confluence of themes and ideas that I wish to discuss: the irruption of violence within quotidian domestic space and its cinematic representation. To a large extent, these are the themes that Haneke has returned to repeatedly (Wheatley 2009). Or, with slightly different emphasis, McCann and Sorfa (2011:3) describe the three tenets of Haneke's on-going cinematic project as being concerned with 'ethics, audience, and power'. Each of these underpin the coming discussion.

Funny Games and Funny Games U.S. both lend themselves to an analysis through the broad framework of Picart and Greek's (2007) 'gothic criminology'. This seeks to examine the construction of the monstrous and/or criminal "Other" within the social imaginary. For Murdock (1997 cited in Kimber 2011: 56), we can look to genre films as 'symbolic lagoons of social fears'. In dredging and filtering these particular "lagoons", we can see how Haneke plays with genre convention yet also draws upon contemporary depictions of the monstrous that is without 'mythic origin' (Colavito 2008: 380). More narrowly, I examine the ways in which the presence of an antagonistic Other within the home prompts an uncanny blurring of boundaries. As such, I look to both Derridean notions of hospitality and the enforced intimacy of Grand Guignol theatre to unpack the ways in which the violence of the unknown (and unknowable) Other in Funny Games problematizes the space of the home, as well as that of the film itself. Indeed, there are two invasions in Funny Games; the first within the diegetic world and the second within the situated viewing experience of the audience. 
The structure of this article is akin to a dolly shot arranged by an omnipotent cinematographer. An initial close-up on the smallest, mundane details (the making of a sandwich) leans-back to reveal the home, family and antagonists in a medium shot. The camera pulls back further to puncture the television screen and take in the living room of the viewer. It then settles on the open DVD case of Funny Games that rests on top of a well-thumbed copy of Cahiers du Cinema (with a copy of Fangoria lurking between its covers). Or, to put this slightly more coherently, we move from a tight focus on the text of Funny Games before examining the effect within and outside the text of its fourth wall-breaking. We then finish by looking at Funny Games as a cinematic product.

A brief synopsis should prove useful at this point. Funny Games (1997) begins with a family (husband Georg, wife Anna, son Schorschi ${ }^{1}$ and dog Rolfi) on their way to their lakeside holiday home. The diegetic classical soundtrack - part of a guessing game that the family play on the car stereo - is violently interrupted by the extradiegetic score of John Zorn's industrial piece 'Bonehead' and the opening blood red credits. Before getting to the house, they have a stilted conversation with their neighbours. They notice a figure that they do not know, dressed entirely in white, stood next to the couple. They drive on. As the husband and son ready the family's boat on the lake, the wife prepares a meal. Schorschi interrupts her; there is someone at the screen door at the rear of the house. A teenager, dressed in white, says that he has come on behalf of the family that they had seen earlier. He asks to borrow some eggs. He drops them. He asks for more. He drops those. The wife becomes increasingly irritated. Another - similarly dressed - youth joins them. They are called Peter and Paul. The wife asks them to leave. The husband and son return. The husband, initially confused by his wife's reaction, asks the boys to leave. There is a brief scuffle and the husband is hit across the leg with a golf club. The funny games begin. A game of "hot or cold" reveals that Rolfi has been killed. In a dark mirror of the earlier sequence, Ann - stood alongside Paul - has a stilted conversation with a second set of neighbours at the lake's edge. The antagonists place a wager with the family (and the audience): each member of the family will be dead by nine the following morning. The boys play "cat in the bag" by placing a cushion cover over the son's head. Later, the boy escapes. He swims and runs to the house of the family that they had seen first. He finds their bodies, including that of their child. He is recaptured. The teenagers play "eenie meanie" and Schorschi is shot in front of his parents. A game of "the loving wife" precedes the husband being stabbed and then shot. There is a sequence just prior to the shooting of Georg when Anna grabs a shotgun (helpfully foreshadowed earlier in the film according to genre convention) and shoots Peter. Paul scrambles for the family's remote control and then rewinds the film. The action spools backwards. The cathartic act of revenge is unmade. The film begins again. Now Paul grabs the shotgun before Anna. The wife is drowned at eight the following morning (earlier than planned since the boys have grown hungry). The film ends with Peter and Paul arriving at the house of the second family that Paul had spoken to earlier.

Provocatively, Haneke (cited in Sorfa 2006: 93) said of Funny Games that '[a]nybody who leaves the cinema doesn't need the film, and anybody who stay does'. Clearly this speaks to the ethical response that Haneke hopes to prompt. However, as I argue here, the film is at its most effective in a domestic context. It is not that we 
choose to leave a cinema, rather the aperture between film and home is punctured. The viewer's domestic space is invaded.

Following the structure outlined above, it is time to pull focus onto the domestic and the interplay between the protagonists and antagonists within the home.

\section{MEDIUM SHOT: Hospitality and 'that unbearable orb of intimacy that melts into hate'}

It is often the case within the genre that 'home invasion' is a misnomer. Far from 'invading' - initially at least - the antagonists are welcomed into the home by the protagonists. They are given hospitality. They are brought close within the safety of the domestic. When the conditions of the proffered hospitality change, so it is that the protagonists attempt to eject or remove the antagonists. Perhaps 'home defence' would be more fitting. It is worth exploring the issues surrounding the giving of hospitality before seeing how that curdles. In Funny Games, the first antagonist is welcomed in. Shortly afterwards - once the eggs have been dropped repeatedly Anna goes to the screen door to see both antagonists already stood in the hallway. They have been driven there, seemingly, by Rolfi the dog. They then proceed to outstay their welcome. There is an indefinable unease as the boys perform what amounts to a Garfinkel-like (1967) breaching experiment. Their requests, whilst not immediately unreasonable, are outside of the usual interaction of host and guest. They are repeated pinpricks at the thin carapace of social convention before a golf club is driven through it. We see the beginnings of the passage from, in Dufourmantelle's exquisite phrasing, that 'unbearable orb of intimacy' to a state of hatred (Derrida 2000: 4). That initial interaction - an invitation to cross the threshold and the offer of help - brings into focus the Derridean reading of the 'unconditional injunction' to provide hospitality (cited in Geyh, 2011: 108).

We might point to the house being 'the most primitive drawing of a line that produces an inside opposed to an outside'. That line is breached in myriad ways (Wigley 1996: 104). It is how the 'house[...]pretends to afford the utmost security while opening itself to the secret intrusion of terror' (Vidler 1992: 11). Where the demarcations might be clear, the boundary lines themselves are porous. They are subject to confusion and probing. It is useful here to reference Lacan's notion of extimité (Dolar 1991). Finding no French analogue for uncanny (linguistically tied, as it is, to the unhomely, the doubled and the unkennable), Lacan suggested that extimité could describe the confusion of internal and external states that float through it. To give examples within a domestic setting, Lefebvre (1991), for example, describes the networks running through homes. The home, in this reading, is made up of the conjunction of countless nodal points. For example, there are telecommunications and utilities that puncture that clear demarcating line of inside and out. Gas and electricity lines run through walls, under floors and within ceilings. Our wi-fi signals permeate our homes and those of others. Homes become singular knots in the wider social rhizome, as individual flats stack up to make tower blocks and houses make streets. Each are criss-crossed by such lines and flows of energies. Those central tenets of Haneke's work: immigration, terrorism and cultural identity themselves relate to the puncturing of the line separating internal and external at individual through to international levels. The home becomes the locus for the analysis of these issues in his 
work. This brings us to the idea of hospitality being a consideration of "property, sovereignty and control'2 (Geyh 2011: 108). In this sense, following Geyh (2011), there must first be a host within their home/property/so vereign nation who can offer hospitality to an outsider. They can, or rather must, have some control over the guest in order to maintain the integrity of the home: 'a bad guest [may] result in the displacement, undermining or destruction of everything - and everyone - in the house' (Geyh 2011: 108). Or, as Derrida (2000: 54/5) put it:

I want to be master at home ... to be able to receive whomever I like there. Anyone who encroaches on my 'at home', on my ipseity, on my power of hospitality, on my sovereignty as host, I start to regard as an undesirable foreigner, and virtually as an enemy. This other becomes a hostile subject, and I risk becoming their hostage.

So, a threat to home becomes a threat to selfhood and individuality. The boundaries between domestic space and individuality are also blurry. An attack on one is an attack on both.

There is an onus on the host to regulate the guest. This might well prove contrary to the unconditional injunction to provide hospitality. For Derrida, this opens up hospitality along two branches: absolute hospitality and conditional hospitality. The former requires no knowledge of the outsider. Their anonymity can be complete. They need not proffer their social status, nor even their name. They may be truly unk nown. A conditional hospitality may see the host enquiring after the guest's names. There is power in this. This allows the host to maintain the integrity of the house: 'in telling me what your name is, in responding to this request, you are responding on your own behalf, you are responsible before the law and before your hosts, you are subject in law' (Derrida 2000: 27). This is toyed with by the antagonists of Funny Games. They are floating signifiers. They knowingly play with this and how it disrupts the expected narrative structure of the film. Their names flit between Catholic saints (Peter and Paul) and cartoon characters (using both Hanna Barbera's Tom and Jerry, as well as MTV's Beavis and Butthead). Further, it means that the conditional hospitality offered by the host - dependant on knowing a name - is fatally undermined. Now, they are unknowable before the law and therefore outside of responsibility. The ability to discriminate is taken from the host. The path is set for the host (and their family) to transform 'from a host into a hostage' (Kearney 2003: 68). Hospitality and hostility are elided.

Yet, what should the nature, shape, or scope of the control to be enacted by the host look like? Derrida (2000: 51) asks 'should one hand over one's guests to criminals, rapists or murderers? or lie to them so as to save the people one is putting up and for whom one feels responsible?'. This is the question that prompts the climactic siege in Peckinpah's (1971) Straw Dogs. It also prompts Lot to offer his virgin daughters to a murderous, raping mob in the city of Sodom when they demand to have his angelic guests released to them. In both cases, the hospitality offered to the Other threatens the integrity of the familial relationships within the home whilst privileging the safety of the guest(s).

A conflicted ipseity combines with an external force that further threatens it $^{3}$. However, as should be clear by now, the externality of that threat is questionable. As 
Derrida (cited in Geyh 2011: 11) puts it, 'the Other is already inside, and has to be sheltered and welcomed in a certain way'. The home is porous. It is also the audience's gaze that punctures the walls to look at the home of the protagonists. However, in Funny Games it is the antagonists' look that breaks the fourth wall and gazes back at $u s$.

\section{Breaking the fourth wall: implicating the audience in on-screen violence}

Much has been written relating to an audience's look with regard to violence (Sontag 2003; Young 2010). In reference to crime scene or battlefield photography, a central question revolves around the right of the audience to look. Sontag (2003: 37) suggests that there are those with the ability to change the material conditions of those affected, to 'alleviate' the pain of the violence inflicted by the look. The rest are simply voyeurs: 'whether or not we mean to be' (Sontag 2003: 37). In a key phrase, Sontag (2003: 99) labels these 'consumers of violence as spectacle' or 'adepts of proximity without risk'. With Funny Games there are various techniques used to implicate the audience beyond consumption or voyeurism. These are ways of pushing past the cynicism that Sontag talks about in an effort to force the audience into a selfreflexivity relating to the violence that they are watching. They are not allowed to simply observe. Rather, the audience is provoked into responding.

At several points during Funny Games, Paul breaks the fourth wall. He directly addresses the audience. He asks them to comment on the action or questions their expectations. The film concludes with a freeze frame. Paul's face is turned to us, framed by the doorway of another unsuspecting and hospitable family. This look through the screen challenges the audience's gaze. It highlights the degree to which an audience is complicit with the on-screen action. Perhaps complicity is insufficient. Rather, there is an intimacy to these asides. There is the suggestion of collusion between antagonist and viewer. As with much genre fare, we know more than the protagonist. Here though, there is a shared awareness of the cinematic world between the antagonist and viewer. Both know what is going on and what is coded to happen. Paul is merely providing what the audience expects and desires. The safe distance between spectator and action is collapsed. As Aaron (2007: 92) puts it, ordinarily a disavowal exists that 'represents a contract between spectator and screen; a contract that sustains the safety of the spectator, licensing a safe indulgence in the unreal'. That disavowal melts away under Paul's toxic gaze. Perhaps it is rather simplistic to be reminded of the tagline to Last House on the Left: 'to avoid fainting keep repeating, it's only a movie, only a movie, only a movie'. We know full well that Funny Games is a film. However, it has seeimingly left the diegetic space and invaded the viewer's home.

This particular interaction between antagonist and audience has echoes of the Grand Guignol theatrical tradition. Reaching its peak of popularity during the two World Wars, the Theatre du Grand-Guignol (1897-1962) was typified by sensational horror. In their history of Grand Guignol, Hand and Wilson (2002: 37) suggest that direct address was used to 'implicate the audience and so intensify the horror.' In so doing, this marked a shift from 'any pretence to naturalism' to 'stylized melodrama' (Hand and Wilson 2002: 37). As an aside, Haneke directed the family in Funny Games to play tragedy and the boys to play comedy. The clash sees, if not, 
melodrama with its attendant heightened emotion and (a knowing) sensationalism, but rather a Pinter-esque comedy of menace.

Clearly there is a difference between direct address within the theatre and on film. Sharing the same physical performance space as the actors will mean that direct address acquires a different quality. However, I would argue that the assumed shared domesticity of the on-screen home and the situated viewing experience of the viewer goes some way to mitigate against this. Perkins (2005 cited in Brown 2012: xi) insists that for the cinematic direct addressee 'there is no camera in their world'. This suggests that the projection screen acts as an aperture between worlds. It is a point of ingress and egress, as porous as any of the homes that are invaded. This renders the uncanniness of the invasion into the viewer's home all the more acute. Alternatively, Funny Games would suggest that Paul is very much aware of the camera within his world. Paul is aware of the 'filmness' of Funny Games, its genre tropes and conventions. An alternative consideration would be to question the 'character-ness' of Paul. As Brown (2012: 9) puts it:

where Willemen uses 'imaginary' in its Lacanian sense to designate the subject of the look at the audience, I would prefer 'symbolic'; it is symbolic of the film-text or filmmaker's attitude towards the viewer's role.

In this sense, they are vehicles for the director. And, as Brown (2012: 26) suggests, 'Haneke's extra-textual discourse makes [his] intention clear. He has stated that he wished to "rape the viewer into autonomy". This, in turn, matches with Augé (1999: 3), in that the passivity of the viewer causes them to identify with 'the camera eye and with the projector or, to be more precise, with the entire process of screening which constitutes the film'. We will return to the production process later, but to develop the discussion of direct address, Brown differentiates between the twin practices of distanciation and instanciation. The former speaks to formal techniques that distance the viewer from the action. They seek to challenge genre convention and codes. The rewinding of the film, thereby denying the revenge of the family and a welcome resolution is an example of such a technique. There is no outlet, no moment of catharsis, for the audience. Their trauma becomes enduring. Brown (2012: 16), however, reframes this rewinding of the film as 'instanciation' where it is read as 'a term that suggests the present-ness and immediacy of direct address'. For Brown (2012: 28/9)

Haneke's practice here differs from that of Brecht because the latter wished to make the viewer active in imagining alternatives (political and/or narrative), while Haneke seeks, rather, to victimise and condemn and use our passivity as removed spectators against us.

In addition to the ways in which the antagonist crosses over into our space outside of the film, there are formal cinematic techniques that Haneke employs to draw the viewer more closely to the diegetic world. Rhodes (2010) points to the effects of long-takes and depth-of-focus cinematography to prompt or provoke responses in the audience. Drawing on Bazin (1971/2002), Rhodes (2010) points to the more 'realistic' nature of depth-of-focus photography. We can take the ten minute sequence following the killing of the couple's child as an exemplar. The camera 
remains locked in position, taking in the living room. The image on the bloodspattered television changes, but our attention is drawn first to the shuffling of Anna. Bound, she struggles to move across the room to her husband who is not yet visible behind a sofa. It is perhaps at this point, as our eyes flick over the screen, that we see the body of Schorschi. It is the Barthesian punctum. So, it is not the framing of the shot, nor the editing of the action that determine what we see, don't see or unsee. Rather, it is us. We are 'forced to discern' (Bazin 1971/2002 cited in Rhodes 2010: 89): we "must scrutinise the image, deconstruct it, consider the margins and borders of the frame, and "contemplate" the structure of representational strategies that informed the creation of this image' (Wheatley 2009: 93).

So, the direct address of the look of the antagonist renders us complicit whilst the 'instanciation' of the rewinding of the film critiques us for our passivity. In one instance, the aperture between reel and real worlds is vanishingly thin, whereas with the other, we have the mechanism of the film itself used to condemn us for our inaction. As Gerbaz (2011: 169) puts it, 'viewers are being reminded, by Paul and by Haneke himself, that this whole ordeal, this spectacle of suffering, has been constructed for our benefit'. The violence that occurs does so 'only because the audience expects it' (emphasis added Wheatley 2009: 96).

\section{The performance of violence}

The majority of the violence during Funny Games occurs off-screen. We do not see Rolfi being killed. We simply watch him flop lifelessly from the back of the family car. Schorschi is shot whilst we watch Paul make a sandwich. Georg is stabbed whilst we focus on Anna's jarringly ecstatic expression. He too is finally shot offcamera. Anna is pushed out of the frame. She drowns unseen.

Violence passes unobserved. An edit reveals a fresh bruise or a puffy tearsodden face. Laine (2010) points to the lengthy close-ups on the parents' faces. They become 'the sites of pain and shame for being tortured and humiliated up to the point where both move beyond humiliation, dwelling in a trancelike state' (Laine 2010: 52). This latter observation has clear echoes of Bataille's (1989) reading of an image of slow slicing or death by a 1000 cuts.

This returns us to a consideration of the performance of violence. Again, there are echoes of Grand Guignol. Somewhat counter to popular conceptions, Hand and Wilson (original emphasis 2002: 49) describe Grand Guignol as 'not a theatre of the seen, but the unseen horror, a theatre of restraint rather than the blood-fest it has been presumed to have been'. For Nevitt (2013), a creative collaboration occurs between actor and audience to allow that which is unseen to be seen within the imagination of the audience. Mise en scène, auditorium and imagination become spaces to 'contemplate violence' (Nevitt 2013: 6). The spatial arrangement of the stage itself in Grand Guignol likewise prompted an intimacy between performer and audience. The Grand Guignol stage was relatively small. Plays within this form were rendered claustrophobic, thematically as well as spatially. We see this effect mirrored in Funny Games. It is perhaps not so much that the fourth wall is broken so much that it comes to envelope us in the walls of our own homes. We are provoked into our own unbearable intimacy with the action. On occasion, 'Haneke positions the camera 
alongside the characters: we literally seem to be watching alongside them' (Wheatley 2011: 18). As we sit and watch, we see the family's TV screen (latterly blood spattered), we are mirrored - or we mirror - the family and antagonists sat together on their sofas.

The audience of the film enter a similar relationship with the film-as-text itself. We begin from a position of passivity. We are subject to a 'unilateral violence' (Cavarero 2011:30). Given Haneke's desire to 'rape the viewer into autonomy', there is no parity or reciprocity. We are subject to the film. Haneke and his antagonists exist in a 'position of omnipotence' (Cavarero 2011: 30). Is our only option to really walk away from a film that has already crossed into our viewing space? How much fun is this funny game?

This question re-focuses our attention to the unpleasure of a viewing experience. Wheatley (2009) cites Wollen (1982) in the opposition between 'entertainment' and 'provocation'. In this instance it is precisely the tension between the two states that prompts the ethical reflection in the audience. From the opening sequence of the smiling family driving along, Funny Games draws upon the genre codes and thematic frameworks that it will later upend. In Wheatley's (2009: 83) playful phrasing, 'the family are recognisable as the identikit of fable and fairy tale (father bear, mummy bear, baby bear)'. And, let us not forget, in Southey's (1837) original of The Story of the Three Bears through to the more widely known Goldilocks, the bears successfully repel their indecisive intruder. The thriller elements that follow 'appear as quotes' (Haneke nd cited in Wheatley 2011: 11). There is the framing of the knife on the boat: the everyday object that will be turned on the aggressor in the third act. Similarly, there are several escapes. Haneke (nd cited in Wheatley 2011: 11) describes Schorschi's attempt as 'very classical, like Hitchcock'. Further, the one-dimensionality of the family is, itself, a function of thriller codes. Their purpose is to suffer. The unpleasure comes from the codes being played with and the audience being confronted with an element of violence little seen in thrillers: consequence. For example, the ten minute single shot sequence following the son's murder presents us with an over-determined image, as discussed earlier, but also forces the consideration of a 'scenario unfamiliar in the suspense thriller genre: potential grief not as a motivation for revenge, but as a pure state of being' (Wheatley 2009: 106).

Wheatley (2009) suggests that unpleasure comes form the choice the audience is being called upon to make. Here the clash is between the emotional desire for pleasure and the intellectual recognition that a moral response is required. I would argue that this is further problematized by the viewing experience itself. The place of the film's consumption itself calls into question its consumption. There is far greater control over the film in one's own home. We can pause, rewind, fast forward and eject. We can apply our own editorial hand. One of the central difficulties that John McNaughton's (1986) Henry Portrait of a Serial Killer encountered in receiving home video certification in the UK was precisely based on this issue.

A home invasion sequence exists within Henry and was excised from all versions released in the UK between 1991 and 2003 (Kimber 2011). It featured Henry and his partner Otis breaking into a house, seemingly at random, and murdering a family (as with Funny Games, a mother, father and son). However, '[t]owards the end 
of the scene it is revealed that the viewer is not witnessing the events in real time, but is in fact watching Henry and Otis's home-made "snuff-movie" on their TV back in Otis's apartment, after the event and with the killers' (Kimber 2011: 101). As Kimber (2011: 107) puts it, we are 'formally and thematically positioned[...]alongside Henry and Otis'. They watch the killings as entertainment. Otis pauses, rewinds and rewatches the sequence in slow motion. As with Funny Games, there is a conscious artifice at work here. Yet, the British Board of Film Classification examiners' report (cited in Kimber 2011:35) stated that

The effect of a film within a film here is not to distance it but rather through the home movie feel, give the impression that this could be located anywhere, including one's own home[...]By these devices viewers are invited to participate, to see the titillatory nature of such cruelty and the film is therefore truly exploitative.

As Falcon (1998 cited in Wheatley 2011: 17) states, having a 'domestic viewing context' lends an 'added layer of oppression to a film dealing with a family trapped and tormented within a domestic environment'. In Funny Games, we are formally and thematically placed within the home (as well as our own), but whose side do we take? We are positioned alongside both antagonist and protagonist at various points. The antagonist looks out into our home. When Paul 'reverses' the film, the sound distorts as though the film tape itself is being spooled backwards in a player (in the later remake, both the picture and sound break apart digitally, as though scrubbing a DVD backwards). It is our television that is scrubbing the film backwards.

\section{PULL BACK: production context}

The production context of Funny Games also speaks to the broader themes of extimite and the porousness of borders. The Austrian Haneke worked with a German cast in an Italian location. Price and Rhodes (2010) point to Haneke's year and country of birth (1942, Austria) as offering a 'rather convenient, possibly overdetermined context for thinking about his cinema's meditation on human violence and historical trauma'. Caché (2005), pre-dating Funny Games U.S., and Das Weisse Band (2009) post-dating it, are centrally concerned with a particularly European history of violence. Wheatley (2009:21) explicitly goes further as suggesting that the depiction of violence (its ramifications and representation) references 'Austria's elephant in the corner: the country's complicity with the Nazi regime'. The violence itself takes on a fascistic quality: 'chilling, cold and calculated, rather than cathartic' (Wheatley 2009: 21). It takes place - most often off-camera - in the living rooms of "polite society". In fact, these are the same types of living rooms in which the films are likely to be watched. Protagonists and audience are alike the 'self-described liberals' or 'in a derogatory term "Spiessburger"' (Speck 2010: 15).

The invading Other's position as outsider allows them to offer critique of these groups. Derrida (2000: 5) evokes Plato in stating that 'it is often the foreigner (xenos) who questions'. It is certainly the case that in Funny Games the antagonists' ambiguous outsider status is used to critique the bourgeois family (McCann and Sorfa 2011). This is something of a trope of the genre. It appears, for example, with particularly vicious force in The Last House of the Left (1972, dir W Craven; Fiddler 
2013; Lowenstein 2005). As Sharrett (2010: 216) puts is, 'the external threat to the bourgeois couple may be read as an exteriorization of the deep internal strife of bourgeois married life'. Likewise, Haneke (cited in Justice 2011: 102) has argued that this particular family are 'trapped in a sense by their bourgeois notions and accoutrements, not just by the killers alone'.

Herein lies an ironic paradox (Galt 2010). If Caché most explicitly (and Funny Games offers a thin thread here with its conflict between "cosmopolitanism and hospitality') queries the "colonial and marginal "others", can it do so from a position as an artefact of cultural centrality (Galt 2010: 222)? It questions the borders, both historically and contemporaneously, but is itself a product with 'a strong association with European power and privilege' (Galt 2010: 222). To back up slightly, this wider context of European film production merits elaboration. The context of Haneke, his films and their production alike, is of a Europe whose borders are in constant flux. In Galt's apposite phrasing, we can picture a Europe 'doubled by the fall of Eurocommunism...its shape, definition and centre of gravity repeatedly revised over the course of twenty years' (emphasis added, Galt, 2010: 226). It is centrally concerned with porous boundaries, liminal geopolitical spaces, definitions of exteriority, interiority and the construction of transient Others. As Mulvey (1992: 56) puts it, the 'homestead as signifier of stable space' acquires a particular resonance when placed in contrast to 'nomadism'. So it is that the 'boundary that secures the cohesive limits of the western nation may imperceptibly turn into a contentious internal liminality' (Bhabhba 1990 cited in Vidler 1992: 10-11). For Galt (2010: 226), Haneke's films encode 'the violent rupture of borders and edges, and the impossibility of inscribing European territory in any secure or centred fashion'. Of course, such discussions are not limited to Europe. The 2007 remake, produced by a conglomeration of production companies based in the US, Austria, Germany, the UK, France and Italy, 'comes with a new set of intertexts' (Wheatley 2009: 193).

\section{Repetition and doubling in Funny Games U.S.}

Released in 2007, Funny Games U.S. is essentially a shot-for-shot remake of the 1997 original. Some lines of dialogue differ: Paul, for example, alludes to the violence of videogame culture on two occasions. Almost entirely though this is an English language doubling of the original. This, however, is not out of keeping for Haneke's work:

Michael Haneke's films clearly bear the marks of creation by a classic auteur: the recurring use of names (George and Ann), stories (the breaking down of the basic family unit), plot devices (real or imagined traumata, an open ending), motifs (the droning noise of television, sudden violence without justification or explanation) and signature shots, such as the extreme close-up on objects of ritualised actions (preparing breakfast)[...].

(Speck 2011: 49)

There are various reasons one might posit for a remake of a little seen art house film from the late $90 \mathrm{~s}^{4}$. The casting could be seen as a means to speak to 'those who need the film'. Alternatively, this is a further layering of the funny game. Rather 
than attracting a new audience who 'needed' the film and would be attracted by the Hollywood casting and lack of subtitles, it was seen instead by the self same Spiessburger audiences who had watched the original. It is they who would, again, subject themselves to the film: as with 'so many victims of the abject [becoming] its fascinated victims - if not its submissive and willing ones' (Kristeva 1982: 9).

The remake, likewise, is a logical consequence of the genre conventions of the piece, as well as the structural 'rules' established in the first film. As Price (2010: 43) indicates, the film could only ever be re-made 'as same'. A happy ending, in the style of the English language remake of The Vanishing, is already negated by the moment of Paul's re-winding. Whilst the film remains the same, we are left to examine the contextual changes. Beney (2008 cited by Speck 2010: 32) suggests that there could be a series: "Funny Games Iraq" or "Funny Games China" each like the last, each prompting an examination of context. A paratextual analysis of the Artificial Eye DVD release of the original draws our attention to the hooded figure of Schorschi on the sleeve. It evokes the images of Abu Ghraib detainees held between the two films. It points to the continued use of torture as both instrument of the State, as well as subject of entertainment.

\section{WIPE: Playing Funny Games}

It is the notion of torture as entertainment that is key. That degree of delight in the pain of others is inverted and turned upon us, the viewers. We are no 'simple consumer' when watching the film (Haneke nd cited in McCann and Sorfa 2011:4). The audience is called upon to commit. We endure or we leave. If we are 'entertained' by something that, ostensibly, shares the trappings of genre convention, then we are to be 'raped into autonomy'. The use of direct address implicates the audience in different ways. Young (2010:17) makes the observation that

Crimes of violence are conventionally constructed as distant from us [...]but the cinematic scene of violence brings such events close to us[...].

In Funny Games, the antagonists' direct address to the audience complicates this. Just as they break the fourth wall, so - akin to one of Garfinkel's (1967) breeching experiments - the film punctures our world and forces us to consider our own response to these depictions of violence.

The film itself is narratively 'slight'. The protagonists are thinly drawn and the antagonists' motivations are frustratingly opaque. The former, however, points to the possibility of an intertextual analysis of Haneke's broader cinematic project (the recurrent use of Ann/a and Georg/e as lead character names, for example), as well as those within the genre field itself. The latter points to their roles as floating signifiers and a current emphasis placed on violent acts rather than characters (Colavito 2008). We can use this particular film then as a framework from which to explore an ongoing confluence of violence, entertainment and spectatorship. A focus on the violence of the invasion itself can be pivoted so that we examine less its representation, but more the complicity of the audience. The 'fourth wall' breaking draws these threads together and heightens them. As Young (2010:24) succinctly 
puts it, 'violence is a cinematic staple'. Funny Games meticulously unravels the audience expectation that 'the violence of wrong-doing can be met with violence' (Young 2010: 24). Here that cathartic violence is reversed. It is expunged from the film. We are left with the violence of the antagonists. We are left with an entertainment. And a funny game, played on its audience. 


\section{References}

Aaron, M. (2007), Spectatorship: The power of looking on, London: Wallflower.

Augé, M. (1999), The War of Dreams: Studies in Ethno Fiction (trans. L. Heron), London: Pluto Press.

Bataille, G. (1989), The Tears of Eros, San Francisco: City Lights Books.

Brown, T. (2012), Breaking the Fourth Wall: direct address in the cinema, Edinburgh: Edinburgh University Press.

Burke, E. (1757/2015), A Philosophical Enquiry into the Origin of Our Ideas of the Sublime and Beautiful, Oxford: Oxford University Press.

Cavarero, A. (2011), Horrorism: Naming Contemporary Violence (trans. W. McCuaig), New York: Columbia University Press.

Colavito, J. (2008), Knowing Fear: Science, Knowledge and the Development of the Horror Genre, London: McFarland \& Company Inc.

Craven, Wes (1972), The Last House on the Left, Boston: Hallmark Releasing Corporation.

Derrida, J. (2000), Of Hospitality: Anne Dufourmantelle Invites Jacques Derrida to Respond (trans. R. Bowlby), Stanford: Stanford University Press.

Dolar, M. (1991), "I shall be with you on your wedding-night": Lacan and the Uncanny, October, 58, pp. 5-23.

Douglas, M. (1966), Purity and Danger: An Analysis of Concepts of Pollution and Taboo, London: Routledge.

Fiddler, M. (2013), Playing Funny Games in The Last House on the Left: the uncanny and 'home invasion' genre, Crime Media Culture, 9:3, pp. 281-299.

Galt, R. (2010), 'The Functionary of Mankind: Haneke and Europe', in B. Price and J.D. Rhodes, (eds.), On Michael Haneke, Detroit: Wayne State University Press, pp.221-242.

Garfinkel, H. (1967), Studies in Ethnomethodology, Oxford: Blackwell Publishers.

Gerbaz, A. (2011), 'The ethical screen: Funny Games and the spectacle of pain', in B. McCann and D. Sorfa, (eds.), The Cinema of Michael Haneke, New York: Columbia University Press, pp.163-171.

Geyh, P.E. (2011). 'Cosmopolitan exteriors and cosmopolitan interiors: the city and hospitality in Haneke's Code Unknown', in B. McCann and D. Sorfa, (eds.), The Cinema of Michael Haneke, New York: Columbia University Press, pp.105-114. 
Hand, R.J. and Wilson, M. (2002), Grand-Guignol: The French Theatre of Horror, Exeter: University of Exeter Press.

Haneke, Michael (1997), Funny Games, London, Tartan Video Ltd..

Haneke, Michael (2005), Caché, London, Artificial Eye Film Co. Ltd..

Haneke, Michael (2007), Funny Games U.S., London, Tartan Video Ltd..

Haneke, Michael (2009), Das Weisse Band, London, Artificial Eye Film Co. Ltd..

Justice, C. (2011), 'The vacant vacationer: travel as symptom and antidote in Michael Haneke', in B. McCann B and D. Sorfa, (eds.), The Cinema of Michael Haneke. New York: Columbia University Press, pp.94-104.

Kimber, S. (2011), Henry: Portrait of a Serial Killer, Basingstoke: Palgrave Macmillan.

Kristeva, J. (1982), Powers of Horror: An Essay on Abjection, New York: Columbia University Press.

Laine, T. (2010), 'Haneke's 'Funny" Games with the audience (revisited)' in B. Price and J.D. Rhodes, (eds.), On Michael Haneke, Detroit: Wayne State University Press, pp.51-60.

Lefebvre, H. (1991), The Production of Space (trans. D. Nicholson-Smith), Oxford: Blackwell.

Lowenstein, A. (2005), Shocking Representation: Historical Trauma, National Cinema, and the Modern Horror Film, New York: Columbia University Press.

McCann, B. and Sorfa, D. (2011), 'Introduction', in B. McCann and D. Sorfa, (eds.), The Cinema of Michael Haneke, New York: Columbia University Press, pp.1-9.

McNaughton, John (1986), Henry: Portrait of a Serial Killer, London, Optimum Releasing.

Mulvey, L. (1992), 'Pandora: topographies of the mask and curiosity', in B. Colomina, (ed.), Sexuality and Space, New York: Princeton Architectural Press, pp.53-71.

Nevitt, L. (2013), Theatre \& Violence, London: Palgrave Macmillan.

Peckinpah, Sam (1971), Straw Dogs, London, FremantleMedia Enterprises.

Picart, C.J.K. and Greek, C. (2007), 'Introduction: toward a gothic criminology', in C.J.K. Picart and C. Greek, (eds.), Monsters In and Among Us: toward a gothic criminology, Madison: Fairleigh Dickinson University Press, pp.11-43.

Price, B. (2010), 'Pain and limits of representation', in B. Price and J.D. Rhodes, (eds.), On Michael Haneke, Detroit: Wayne State University Press, pp.35-48. 
Price, B. and Rhodes, J.D. (2010), 'Introduction', in B. Price and J.D. Rhodes, (eds.), On Michael Haneke, Detroit: Wayne State University Press, pp.1-11.

Rhodes, J.D. (2010), 'The Spectacle of skepticism: Haneke's long takes', in B. Price and J.D. Rhodes, (eds.), On Michael Haneke, Detroit: Wayne State University Press, pp.87-102.

Sharrett, C. (2010), 'Haneke and the discontents of European culture', in B. Price and J.D. Rhodes, (eds.), On Michael Haneke, Detroit: Wayne State University Press, pp.207-219.

Sontag, S. (2003), Regarding The Pain of Others, London: Penguin Books.

Sorfa, D. (2006), 'Uneasy domesticity in the films of Michael Haneke', Studies in European Cinema, 3:2, pp. 93-104.

Speck, O.C. (2010), Funny Frames: The Filmic Concepts of Michael Haneke, London: Continuum.

Speck, O.C. (2011), 'Thinking the event: the virtual in Michael Haneke's films', in B. McCann and D. Sorfa, (eds.), The Cinema of Michael Haneke, Chichester:

Wallflower Press, pp.49-64.

Vidler, A. (1992), The Architectural Uncanny: Essays in the Modern Unhomely, London: MIT Press.

Wheatley, C. (2009), Michael Haneke's Cinema: The Ethic of the Image. Oxford: Berghahn Books.

Wheatley, C. (2011), 'Domestic invasion: Michael Haneke and home audiences', in B. McCann and D. Sorfa, (eds.), The Cinema of Michael Haneke, Chichester:

Wallflower Press, pp.10-23.

Young, A. (2010), The Scene of Violence: Cinema, Crime, Affect, London: Routledge Cavendish. 
${ }^{1}$ Cast Funny Games (1997): Anna (Susanne Lothar), Georg (Ulrich Mühe), Schorschi (Stefan Clapczynski), Peter (Frank Giering) and Paul (Arno Frisch).

Cast Funny Games U.S. (2007): Ann (Naomi Watts), George (Tim Roth), Georgie (Devon Gearhart), Peter (Brady Corbet) and Paul (Michael Pitt).

${ }^{2}$ These overlap with what Price and Rhodes (2010: 8) identify as recurrent themes within Michael Haneke's work: 'immigration, terrorism and cultural identity'

${ }^{3}$ We might be reminded here of Kristeva's (1982: 4) unpacking of the abject: 'It is[...] what disturbs identity, system, order. What does not respect borders, positions, rules. The in-between, the ambiguous, the composite.'

${ }^{4}$ Wheatley (2009) puts the UK cinema gross for Funny Games at $£ 33,727$. 